\title{
Docking and Homology Modelling of Human T-Helper Cells for Various SCFV Fragments Domains to Block the Access of GP120
}

\author{
Jayalakshmi T, R.Priya, K. Vijayalakshmi
}

\begin{abstract}
HIV (Human Immunodeficiency Virus) is a virus which directly attacks human immune system as well as certain body organs such as brain kidneys and heart. The resistant framework is comprised of unique cells, which are associated with shielding the body from contaminations and a few tumors. The essential cells assaulted by HIV are the CD4+ lymphocytes, which help direct invulnerable capacity in the body. Since CD4+ cells are required for appropriate resistant framework work, when enough CD4+ lymphocytes have been devastated by HIV, the safe framework scarcely works. A considerable lot of the issues experienced by individuals contaminated with HIV result from a disappointment of the resistant framework to shield them from certain artful diseases (OIs) and tumors. This situation is utilized in a reasonable universe of bioinformatics in order to shape conceivable structure of the HIV gp120 which is reason for T cell contamination and a structure of the cd4+, to think about the coupling example of the gp120 and cd4+ through the docking procedure.
\end{abstract}

KeyWords - HIV, Artful Diseases

\section{INTRODUCTION}

The process that takes place in biology can be understand using various pathways and also by using various bioinfromatics. Computational methods can be applied and can be determined with the help of docking studies ${ }^{[1]}$. The major field includes genomics and proteomics where by using software tools gene prediction and expression methods are described

Steps involved in protein construction are:

The development of a structure layout database:

Select protein structures from the protein structure databases as basic layouts. This for the most part includes choosing protein structures from databases, for example, PDB, FSSP, $\mathrm{SCOP}$, or CATH, in the wake of expelling protein structures with high grouping likenesses .

grouping at their adjusted spine places of the chose auxiliary format.

\section{MATERIALS AND METHODS}

Revised Manuscript Received on July 22, 2019

Jayalakshmi, Professor, Department of Genetics, Bharath Institute of Higher Education and Research (BIHER), Chennai -600073.

Jayamaniraaja07@gmail.com

Ms. K. Vijayalakshmi, Department of Genetics, Bharath Institute of Higher Education and Research (BIHER), Chennai -600073

kdmviji@gmail.com

Dr. R. Priya Department of Genetics, Bharath Institute of Higher

Education and Research (BIHER

Priya.microbio@gmail.com

\section{A. Ab initio protein modeling:-}

$A b$ initio- or de novo- protein modeling methods helps to build 3-D protein models "from scratch The protein prediction methods can be used in algorithms and can be determined by various computational resources where large sequences can be seen and modeling can be [2 ],[4],[6] Little particle docked to a protein.

In the field of sub-atomic displaying, Docking is a method that predicts the preferred entry of one particle to another when bound to frame a constant perplexing. Information on the preferred implementation could therefore be used to anticipate the quality of membership or to restrict the partiality between two particles using scoring capabilities, for example[7],[9],[11]

\section{B. Monte Carlo methods}

An initial configuration in Monte Carlo is refined by taking random steps that are accepted or rejected on the basis of their induced score improvement until a certain number of steps have been tried[19],[21],[23]. The assumption is that from a large class of initial configurations, only one of which must be considered, convergence to the best structure should occur. Cows can be sampled in initial configurations Drug designing process

GOLD is a program for ascertaining the docking methods of little atoms in protein restricting destinations and is given as a feature of the GOLD Suite, a bundle of projects for structure perception and control (Hermes), for protein-ligand docking (GOLD) and for post-handling (GoldMine) and representation of docking results. Hermes goes about as a center point for a significant number of CCDC's items, for more data please allude to the Hermes item page.

\section{RESULTS}

A. Result of the required molecule

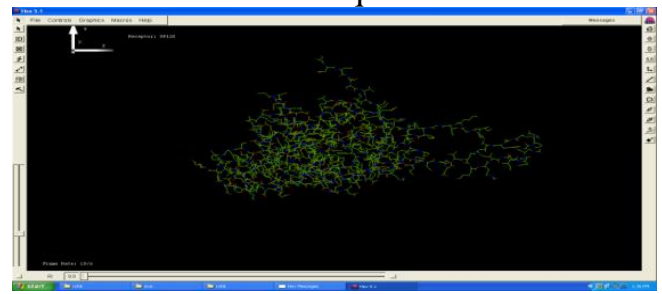

Fig 1.Protein-ligand molecule 


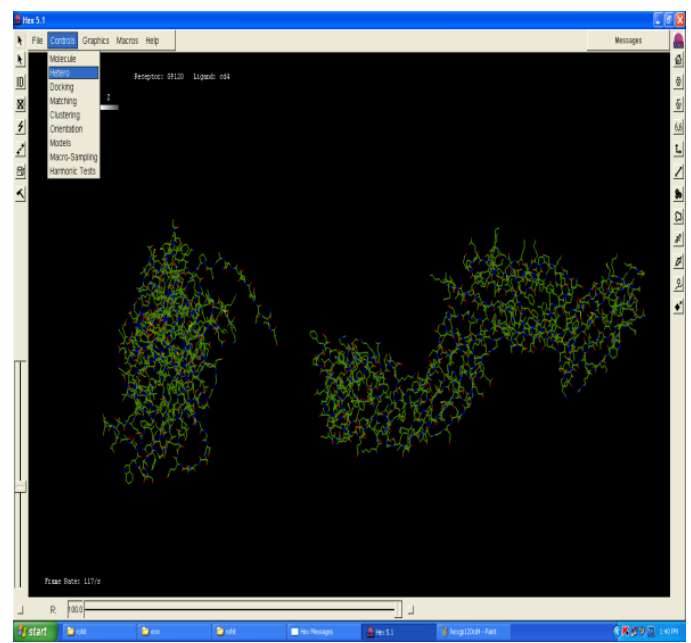

Figure 2. Image displying both the receptor and ligand

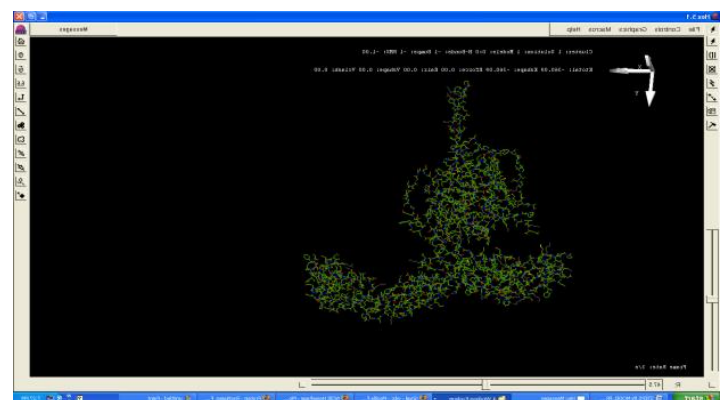

Fig 3.Image displaying the final structure of the complex consisting of GP120 and CD4+

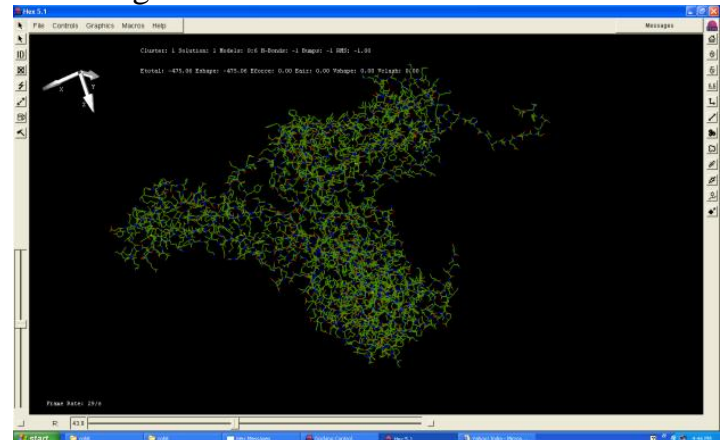

Fig 4.Image displaying the final structure of the complex consisting of GP120 and CD4+

\section{DISCUSSION}

Prediction of a target protein's three-dimensional structure from a homologous (template) protein's amino acid sequence (main structure) for which an X-ray or NMR structure is accessible. According to the protein structure expectation techniques like Homology Modeling, Threading and $\mathrm{Ab}$ initio strategies, we should discover the format for our grouping of intrigue. While finding the format we have searched for the \% character or similitude between the succession of intrigue and layout. According to the displaying situation, if the $\%$ personality is over $60 \%$, we ought to go for Homology demonstrating, if is in the scope of 25-60\%; ought to go for threading technique and on the off chance that it is beneath 20-25\%; ought to go for $\mathrm{Ab}$ Initio strategy[25],[27],[29].

According to the \% character we have from layout in the wake of sending format determination ask for either through Swiss PDB watcher or straightforwardly through the online
Swiss model server, we have picked the homology demonstrating strategy for structure forecast. Modeling for the Sequences of interest has done by Swiss PDB Viewer offline tool or by directly the automated mode for structure prediction available online on Swiss-Model Server. It has given us with the final predicted structure based on the template structure.

In docking, we are supposed to manipulate the receptor and ligand molecules before we will be going for docking. Manipulations are to be done according to the Tool which we are going to use for docking purpose. Here we have used Hex docking platform which has manipulating criteria in terms of enabling solvent, enabling hetero and enabling Arg/Lysine. When we have started with the docking, first thing we considered is Estart and then simultaneously Emin and Emax[32],[34],[36]. These values are to be considered energy should be minimized so as to make the molecule stable as, more the rotatable bonds in ligand, the more difficult it will be to find good binding modes in repeated docking experiments. Thus final result that is the Etotal should lie in between Emin and Emax. ETotal should be always less so as to get the maximum stability to docking complex for perfect merge and also less than Estart.

\section{CONCLUSION}

CD4 (differentiation cluster 4) is a glycoprotein expressed on the surface of T-cells, monocytes, macrophages, and dendritic cells. It was found in the late 1970s and was initially referred to as leu-3 and T4 (after the reaction. The CD4 protein is produced by the gene CD4 In the homology displaying structure expectation strategy, we have anticipated the structure of HIV1 gp120 and Human CD4+. \% character demonstrates the similitude in capacities. According to the $\%$ personality we got which is over $60 \%$, we made with the end that our arrangement of intrigue has identical capacity as that of the layout. That implies, (clarify the capacity of cd4+ n hiv1gp120).

According to the dialogs, the ETotal for the HIV gp120 and human CD4+should be not exactly Estart and should lie in the middle of Emin and Emax. According to the docking results we got EStart was $47.50 \mathrm{KJ} / \mathrm{mol}$ and our Etotal is-244.0 KJ/mol. So it is not exactly Estart and it's all the more lying towards Emin[42],[44],[46]. So we are getting steady mind boggling according to the docking result. So this docking complex is substantial one complex and these two particles gp120 and cd4+ are having restricting proclivity which really implied for the HIV disease.

\section{REFERENCES}

1) Sharmila S., Jeyanthi Rebecca L., Das M.P.,Production of Biodiesel from Chaetomorpha antennina and Gracilaria corticata,Journal of Chemical and Pharmaceutical Research,V-4,I-11,PP-4870-4874,Y-2012

2) Aarthi C., Ramesh Babu P.B.,Anti-cancer activity of Phyllanthus reticulatus on colon cancer cell line, International Journal of Civil Engineering and Technology,V-8,I-1,PP-943-947,Y-2017

3) Sharmila S., Jeyanthi Rebecca L., Das M.P., Saduzzaman M.,Isolation and partial purification of protease from

plant 
leaves,Journal of Chemical and Pharmaceutical Research,V-4,I-8,PP-3808-3812,Y-2012

Jayalakshmi T., Krishnamoorthy P., Ramesh Babu P.B., Vidhya B.,Production, purification and Biochemical characterization of alkaline Fibrinolytic enzyme from Bacillus subtilisstrain-GBRC1,Journal of Chemical and Pharmaceutical Research,V-4,I-12,PP-5027-5031,Y-2012

5) Jeyanthi Rebecca L., Susithra G., Sharmila S., Das M.P.,Isolation and screening of chitinase producing Serratia marcescens from soil,Journal of Chemical and Pharmaceutical Research,V-5,I-2,PP-192-195,Y-2013

Aarthi C., Ramesh Babu P.B.,Antimicrobial and antioxidant activity of phyllanthus niruri,International Journal of Pharmacy and Technology,V-8,I-2,PP-14701-14707,Y-2016

Anbuselvi S., Jeyanthi Rebecca L., Sathish Kumar M. Senthilvelan T.,GC-MS study of phytochemicals in black gram using two different organic manures,Journal of Chemical and Pharmaceutical Research,V-4,I-2,PP-1246-1250,Y-2012

Soniyapriyadharishni A.K., Ramesh Babu P.B.,Data mining strategies for identification of HNF4A MODY gene using gene prioritize tool,Journal of Chemical and Pharmaceutical Research,V-6,I-3,PP-1126-1133,Y-2014

Sharmila S., Jeyanthi Rebecca L., Naveen Chandran P., Kowsalya E., Dutta H., Ray S., Kripanand N.R., Extraction of biofuel from seaweed and analyse its engine performance, International Journal of Pharmacy and Technology,V-7,I-2,PP-8870-8875,Y-2015

10) Sharmila S., Jeyanthi Rebecca L., Saduzzaman M.,Biodegradation of domestic effluent using different solvent extracts of Murraya koenigii,Journal of Chemical and Pharmaceutical Research,V-5,I-2,PP-279-282,Y-2013

11) Jeyanthi Rebecca L., Sharmila S., Das M.P., Seshiah C.,Extraction and purification of carotenoids from vegetables,Journal of Chemical and Pharmaceutical Research,V-6,I-4,PP-594-598,Y-2014

12) Krishnamoorthy P., Praveen Kumar P.K., Ramesh Babu P.B.,Community based evaluation of phenylthiocarbamide (PTC) sensitivity and Dermatoglyphics as a genetic marker in Tamilnadu, India,International Journal of Pharmacy and Technology,V-5,I-3,PP-5705-5712,Y-2013

13) Sharmila S., Jeyanthi Rebecca L.,GC-MS Analysis of esters of fatty acid present in biodiesel produced from Cladophora vagabunda,Journal of Chemical and Pharmaceutical Research,V-4,I-11,PP-4883-4887,Y-2012

14) Sinha S., Rajasulochana P., Ramesh Babu P.B., Krishnamoorthy P.,Comparative modelling of shikimate kinase (M Tb) and molecular docking studies of its known inhibitors, Research Journal of Pharmaceutical, Biological and Chemical Sciences, V-4,I-3,PP-715-720,Y-2013

15) Jeyanthi Rebecca L., Dhanalakshmi V., Sharmila S.,Effect of the extract of Ulva sp on pathogenic microorganisms,Journal of Chemical and Pharmaceutical Research,V-4,I-11,PP-4875-4878,Y-2012

16) Sharmila S., Jeyanthi Rebecca J.,A comparative study on the degradation of leather industry effluent by Marine algae,International Journal of Pharmaceutical Sciences Review and Research,V-25,I-2,PP-46-50,Y-2014

17) Ramesh Babu P.B., Krishnamoorthy P., Gayathri G.,Identification of drug target site on citrate synthase of food pathogen - Campylobacter jejuni,Research Journal of Pharmaceutical, Biological and Chemical Sciences, V-4,I-1,PP-618-623,Y-2013

18) Sharmila S., Rebecca Jeyanthi L., Saduzzaman M.,Biodegradation of tannery effluent using Prosopis

juliflora,International Journal of ChemTech Research,V-5,I-5,PP-2186-2192,Y-2013

19) Kumar S., Das M.P., Jeyanthi Rebecca L., Sharmila S.,Isolation and identification of LDPE degrading fungi from municipal solid waste,Journal of Chemical and Pharmaceutical Research,V-5,I-3,PP-78-81,Y-2013

20) Das M.P., Jeyanthi Rebecca L., Sharmila S., Anu, Banerjee A., Kumar D.,Identification and optimization of cultural conditions for chitinase production by Bacillus amyloliquefaciens SM3,Journal of Chemical and Pharmaceutical Research,V-4,I-11,PP-4816-4821,Y-2012

21) Ramesh Babu P.B., Krishnamoorthy P., Rekha R.,Develoment of comprehensive online database model for genes responsible for asthma, Research Journal of Pharmaceutical, Biological and Chemical Sciences, V-4,I-1,PP-865-871,Y-2013

22) Devi M., Jeyanthi Rebecca L., Sumathy S.,Bactericidal activity of the lactic acid bacteria Lactobacillus delbreukii,Journal of Chemical and Pharmaceutical Research,V-5,I-2,PP-176-180,Y-2013

23) Ramesh Babu P.B., Miller T.L., Chidekel A., Shaffer T.H.,Clara cell protein mediates secretion of proteins, IL-8 and IL-6 in human airway epithelial cell line Calu-3 exposed to hyperoxia,Journal of Chemical and Pharmaceutical Research,V-4,I-6,PP-3164-3170,Y-2012

24) Bhuvaneswari B., Hari R., Vasuki R., Suguna,Antioxidant and antihepatotoxic activities of ethanolic extract of Solanum torvum,Asian Journal of Pharmaceutical and Clinical Research,V-5,I-SUPPL. 3,PP-147-150,Y-2012

25) Abraham Samuel F., Mohan V., Jeyanthi Rebecca L.,Physicochemical and heavy metal analysis of sugar mill effluent,Journal of Chemical and Pharmaceutical Research,V-6,I-4,PP-585-587,Y-2014

26) Narayani P.C., Anbu J., Vasuki R., Hari R.,Invitro and invivo anti-arthritic activity of combined ethanolic extracts of Calotropis gigantea and Cardiospermum halicacabum in Wistar rats,Journal of Natural Remedies,V-14,I-1,PP-58-66,Y-2014

27) Paul Das M., Jeyanthi Rebecca L., Sharmila S., Anu, Banerjee A., Kumar D.,Identification and optimization of cultural conditions for chitinase production by Bacillus amyloliquefaciens SM3,Journal of Chemical and Pharmaceutical Research,V-4,I-12,PP-4969-4974,Y-2012

28) Vasuki R., Hari R., Pandian S., Arumugam G.,Hepatoprotective action of ethanolic extracts of eclipta alba and piper longum linn and their combination on CCL 4 induced hepatotoxicity in rats, International Journal of Pharmacy and Pharmaceutical Sciences,V-4,I-SUPPL.1,PP-455-459,Y-2012

29) Saduzaman M., Sharmila S., Jeyanthi Rebecca L.,Efficacy of leaf extract of Moringa oleifera in treating domestic effluent,Journal of Chemical and Pharmaceutical Research,V-5,I-2,PP-139-143,Y-2013

30) Senthil Kumar K., Vasuki R., Priya R.,Green synthesis, pegylation of silver nano herbal complexand study of its anti-mutagenicity activity, International Journal of Pharmacy and Technology,V-8,I-2,PP-12130-12143,Y-2016

31) Srivastava S., Seethalakshmi I., Jeyanthi Rebecca L.,Antimicrobial and antioxidant properties of cissus quandrangularis,Journal of Chemical and Pharmaceutical Research,V-5,I-5,PP-131-134,Y-2013

32) Gireeshan M.G., Vasuki R., Krishnakumar T.,High power production from elephantâ€ $€^{\mathrm{TM}} \mathrm{s}$ urine,International Journal of Pharmacy and Technology,V-6,I-2,PP-6714-6718,Y-2014

33) Jeyanthi Rebecca L., Dhanalakshmi V., Sharmila S., Das M.P.,In 
vitro antimicrobial activity of Gracilaria SP and Enteromorpha $\mathrm{SP}$, Research Journal of Pharmaceutical, Biological and Chemical Sciences, V-4,I-1,PP-693-697,Y-2013 Jeyanthi Rebecca L., Dhanalakshmi V., Thomas T.,A comparison between the effects of three algal extracts against pathogenic bacteria,Journal of Chemical and Pharmaceutical Research,V-4,I-11,PP-4859-4863,Y-2012 MohdHelmyAbdWahab, Amirul A. Talib, Herdawatie A. Kadir, Ayob Johari, A.Noraziah, Roslina M. Sidek, Ariffin A. "Smart cane: assistive cane for visually impairedpeople", IJCSI, Vol.8 Issue 4, July 2011.

36) M. Bousbia-Salah, A. Larbi, and M. Bedda, "An approach for the measurement of distance travelled by blind and visually impaired people," in Proc. 10th IEEE Inter

37) Brabyn, J. A. (1985). A review of mobility aids and means of assessment. In D. H.Warren\&amp; E. R. Strelow (Eds.), Electronic Spatial Sensing For the Blind-ContributionsFrom Perception, Rehabilitation, and Computer Vision (pp. 13- 27). Boston, MA: MartinusNijhoff Publishers

38) Heyes, "A polaroid ultrasonic travel aid for the blind," Journal of Visual Impairment and Blindness, vol. 76, pp. 199-201, 1982.

39) ShrutiDambhare M.E 3rd SEM (ESC) G.H.R.C.E. Nagpur, Prof. A. SakhareM.Tech(ESC) G.H.R.C.E. Nagpur Smart stick for Blind: Obstacle Detection, Artificial vision and Real- time assistance via GPS.

40) Michel Mouly and Marie-Bernadette Pautet: GSM System for Mobile Communicationspublished by the authors 1992, ISBN 2-9507190- 0-7 [4] Majid Al Shamsi, Mahmoud Al- Qutayri, and Jeedella, "Blind Assistant Navigation System" in IEEE Transactions, March 2011.

41) A. R. Garcia, R. Fonseca. A. Duran. \&quot;Electronic long cane for locomotion improving on visual impaired people.\&quot; IEEE, pp.58-61, 2011.

42) G.Gayathri,M.Vishnupriya,R.Nandhini, Ms.M.Banupriya "SMART WALKING STICK FOR VISUALLY IMPAIRED" International JournalOf Engineering And ComputerScience ISSN:2319-7242 Volume 3 Issue 3 March, 2014 Page No. 4057-4061.

43) ArijitDatta "Advanced GPS \&amp; GSM Based Navigation System for Blinds" International Journal for Research in Technological Studies Vol. 1, Issue 6, May 2014 | ISSN (online):2348-1439.

44) Amit Kumar, Rusha Patra, M. Manjunatha, J. Mukhopadhyay and A. K. Majumdar an electronic travel aid for navigation of visually impaired Communication Systems andNetworks (COMSNETS), 2011 Third International conference on 4-8 jan 2011.

45) Shamsi, M.A.; Al-Qutayri, M.; Jeedella, J.; Blind assistant navigation systemBiomedical Engineering (MECBME), 2011 1st Middle East Conference on 2124 Feb. 2011

46) Michel Mouly and Marie-Bernadette Pautet: GSM System for Mobile Communications, published by the authors 1992, ISBN 2-9507190- 0-7 [4] Majid AlShamsi,Mahmoud Al-Qutayri, and Jeedella, "Blind Assistant Navigation System" in IEEETransactions, March 2011.
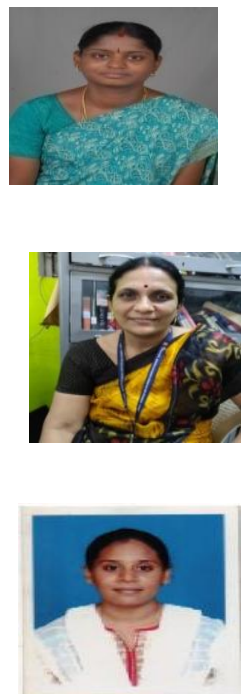

\section{AUTHORS PROFILE}

Jayalakshmi, Professor, Department of Genetics, Bharath Institute of Higher Education and Research (BIHER), Chennai -600073..

Ms. K. Vijayalakshmi, Department of Genetics, Bharath Institute of Higher Education and Research (BIHER), Chennai -600073

Dr. R. Priya Department of Genetics, Bharath Institute of Higher Education and Research (BIHER. 